\title{
Achieving E-procurement Benefits in an Aviation MRO Environment
}

\author{
Munmun Basak \\ Sourcing Specialist - Contracts and Procurement \\ GE Oil and Gas (Australia) Pty Ltd, \\ 51 Barry Alexander Drive, Springfield Central, QLD 4300, Australia \\ Email: munmun.basak@ge.com; munmunbasak123@gmail.com
}

\begin{abstract}
Continuous technological innovations are forcing businesses to bring automation into its core activities. Eprocurement is one of such technological advancement, receives much attention these days as it is a key to optimise supply chain performance, through cost reduction and improved process efficiency. The purpose of this paper is to compare substantial impact of e-procurement and traditional procurement process for MRO (maintenance, repair and overhaul) in an aviation industry through a qualitative case study approach where stages before and after implementation of e-procurement have been analysed to assess the impact on supply chain performance. The study shows that the eprocurement has advantages over the traditional procurement through bringing simplification and transparency throughout the process, reducing turnaround time and also long term relationship with the suppliers along with subsequent cost reduction across the value chain.
\end{abstract}

Keywords: E-procurement, supply chain, maintenance, repair and overhaul, case study, cost reduction

\section{INTRODUCTION: SUBTANTIAL TREND IN MOVING TOWARDS E-PROCUREMENT}

Due to the increasing importance of aviation safety and airworthiness of aircrafts, maintenance, repair and overhaul, (MRO) has become the key division in aviation industry. Aircraft maintenance, repair and overhaul activities invariably demand well-coordinated information technology and communication in place to face challenges in aviation industry. These days business management has entered into the era of internet work oriented competition where the competition is not within brand versus brand, store versus store but in supply chain versus supply chain (Lambert and Cooper, 2000). Companies are struggling to get dominant positions in the market by improving their supply chain as customers evaluate the performance of the organisations based on their SCM performance. Maintaining or repairing fixed wing or rotary wing aircraft is a capital intensive affair for business and to ensure airworthiness and optimal flight efficiency while lowering cost as much as possible, is a challenge for the supply chain where procurement plays an indispensable role.

Procurement is considered as an extremely important as well as expensive business activity for the organisations because organisations spend a huge amount of their operational budget or revenue on purchasing goods and services (Rahim, 2008). Considering the importance of procurement activity in SCM, it is hard to deny the fact that traditional procurement process suffers from few inefficiency problems such as it is a labour-intensive activity where employees spend considerable time on non-value added activities and reconciliation (Chia, 1998, Rahim, 2008), initiate unplanned purchases from non-preferred suppliers at a higher price (Turban et al., 2008), high error rates and long purchase cycle times and complicated and time consuming logistics and fulfilment procedures in taking delivery and dispatching them to the ultimate consumers (Gueritz, 2001). Miah et al. (2013) proposed a decision support system (DSS) approach to address a complex supplier selection decision in the healthcare purchasing. They further raised the need for a DSS that incorporates the integration pf supply chain for achieving an enhanced and accurate decision-making. Kähkönen et al., (2013) described the changes or introduction of a new e-business technologies cause changes in the supply chain and networks, and these changes call for a dynamic approach to integrate the supply chains.

The emergence of e-procurement mechanism quickly gains attention in business to overcome these substantial inefficiencies. E-procurement is basically a tool that enables procurement activities such as sourcing, ordering, commissioning, receipting and making payment (Vaidya $e t$ al., 2004). Existing literatures have revealed various procurement issues in the production supply chain but procurement of material and services used in aircraft maintenance, repair and overhaul activity has much scope for further research. This study contributes in assessing adoption and implementation of e-procurement to achieve benefits in an aviation MRO sector while considering the challenges and issues associated with e-procurement. The information gathered from the study can be used to shape future direction of e-procurement in MRO business.

The objective of this study is to outline procurement processes before and after adoption of e-procurement in an aviation MRO environment to analyse success factors supporting adoption of e-procurement to enhance the efficiency of SCM. This paper has been structured in five sections- section one provides the general idea of the topic, section two describes the background and the motivation for the study, section three explains the methodology adopted, section four contains analysis through a case study and section five summarises the entire study and further scope. 
2. BACKGROUND STUDY: LITERATURE REVIEW OF THE E-PROCUREMENT BENEFITS

Since the inception of the concept of SCM and eprocurement, extensive literature exists on different aspects of SCM and e-procurement in general and provides a broad overview of the concepts such as understanding the benefits of e-procurement (Parida et al, 2006, Gueritz, 2001), current issues and challenges of e-procurement (Williams and Hardy, 2007), assessing the impact of e-procurement (Boer et al,2002), adoption and acceptance of e-procurement and its impact on organisational performance (Gunasekaran and Ngai, 2008, Davila et al., 2003, Rahim, 2008, Pires and Stanton, 2005, Teo et al,. 2009), governance of complex procurement in oil and gas industry (Olsen et al., 2005), eprocurement systems for governmental purchasing (Panayiotou et al., 2004), e-procurement in hotel supply chains (Kothari et al., 2005), and e-procurement and SCM (Presutti, 2003).

Farzin and Nezhad (2010) studied the benefits of eprocurement in the construction supply chain and the drivers and barriers of e-procurement along with framework of supplier selection in an e-procurement environment. Procurement of direct material related with the production of goods always attracts serious attention in literature in comparison with indirect material required for MRO. In fact much potential lies in a MRO supply chain to reduce cost and increase efficiency (Foroughi, 2007) as procurement is a costly activity for the business that needs to be properly structured to make SCM efficient and effective. Power (2008) discussed the potential benefits of utilising technologies in supply chain management may also include, for example, open information sharing, increased visibility of customer demand, decrease in delivery lead times, improved visibility and the development of core competences.

\subsection{SCM and MRO Procurement in Aviation Industries}

A supply chain is a network of facilities and distribution options that begin with the procurement of materials up to rendering service packages to the end consumer (Jain et al., 2010). An efficient supply chain enhances the opportunity of reducing operational costs, improving productivity along with some complex challenges regarding end-to-end integrated planning, increased availability of assets, inventory optimization and effective spend management (Khandelwal, 2011). Procurement is actually a support activity in the supply chain for the purchase of inputs for all parts of the value chain while anticipating requirements, sourcing and obtaining supplies, moving supplies to the organisation, and monitoring the status of supplies as current assets (Pires and Stanton, 2005). Procurement of indirect materials (MRO) is neither part of the end product nor resold directly but is required for maintenance, repair and operation of the company (Puschmann and Alt, 2005). MRO procurement in the aviation industry is actually required for scheduled and preventative maintenance against any technical, mechanical and electrical failure to ensure safety and airworthiness of aircraft.

As procurement engages huge amounts of cash flows in the business so any improvement in procurement process can help to cut down costs incurred in selection of the preferred suppliers, increase the value gained in terms of price and quality, lower transaction cost, shorten lead time and consequently will significantly influence SCM (Lancioni et al., 2000). Figure 1 shows the supply chain model of a helicopter servicing (MRO) company. The procurement of indirect materials (MRO procurement) was not included during the implementation of enterprise resource planning (ERP) systems to optimize the process, due to low strategic importance of the products, low product value and low transaction volume (Puschmann and Alt, 2005).

Traditional procurement processes suffers from a significant number of problems regarding process inefficiencies. First, in this process most of the time organisation is used to make unplanned and non-essential purchases along with poor compliance with corporate contracts which result in rising administrative overhead and payment cost. Second, the lead time or purchase cycle time is higher so companies tend to maintain stock in inventory which turns in higher inventory carrying costs and make SCM ineffective as the major outlook for any SCM is to reduce inventory costs without any shut down in operation (Gueritz, 2001). Third, traditional procurements permit maverick buying practice which means as companies become involved in a situation because of unplanned purchases, they buy from non-preferred suppliers at a higher cost as they lose the ability to negotiate a price with them (Rahim, 2008). Fourth, this process used to be a manual process so the chances of error are high and demands a pool of manpower engaged in reconciliation and non-value added activities. Fifth, complicated and time-consuming logistics and fulfilment procedures take place in taking delivery of the goods as well as dispatching them to the consumers (Gueritz, 2001). Sixth, traditional purchasing processes typically involve a large amount of information processing and communication (Gebauer et al., 1998). 


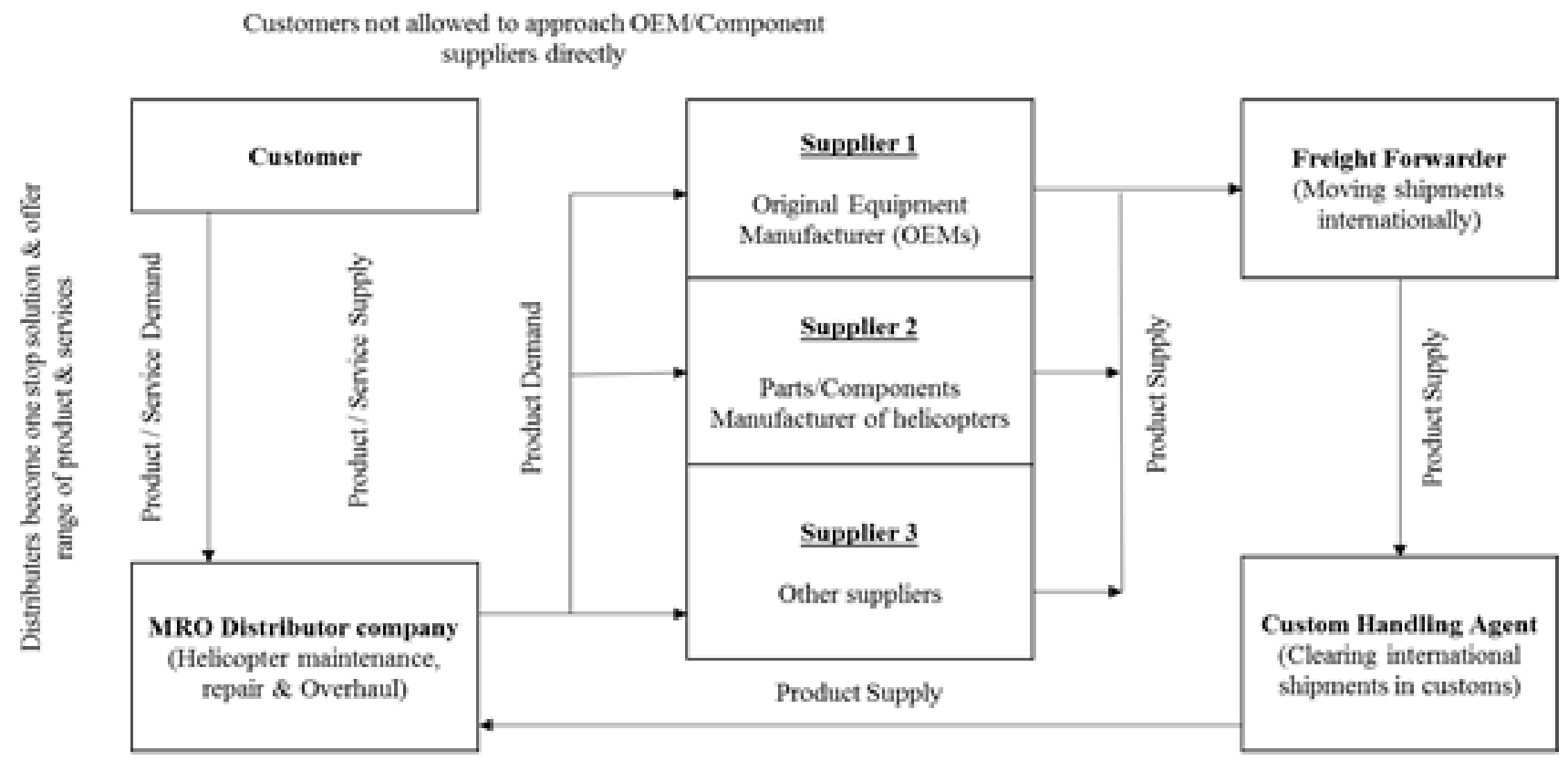

OEM/Component manufacturer dependent on distributors as a route to market

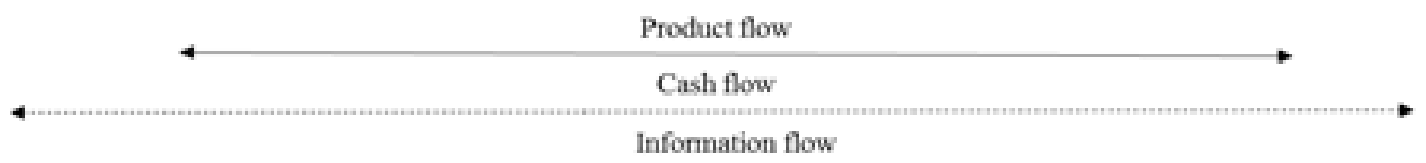

Figure 1 MRO Supply Chain Model

\subsection{E-procurement for MRO and SCM Efficiency}

To eradicate the problems encountered in traditional procurement processes, e-procurement appeared as an internet-based technology that revolutionizes the purchasing process of an organisation by bringing automation into a labour intensive atmosphere. E-procurement is an electronic platform where procurement activities are conducted between different parties involving electronic communication mediums like email, internet, phone, fax, EDI. E-procurement technology supports the acquisition of goods over the internet through engaging e-procurement software, business-to-business market exchanges and purchasing consortia (Davila et al., 2003). According to Gunasekaran et al., (2009), e-procurement initiates the acquisition of resources, especially MRO items which help in significant cost savings and improved effectiveness.

The diffusion of e-procurement systems in the late 1990s has created potential for reorganizing the MRO supply chain (Puschmann and Alt, 2005). E-procurement enhances the efficiency in business-to-business environment by reducing costs, increasing purchase volume, providing a wider range of supplier selection, improving logistics and delivery, reducing paperwork, bringing better quality, and lowering administrative costs (Thomson and Singh, 2001). E-procurement systems provide the flexibility of directly accessing the supplier system to confirm technical specification and description of products, price, catalogue, availability of stock, creating electronic requisition, sending purchase orders to suppliers which eliminate paper-based time consuming cumbersome procedures (Teo et al., 2009). Kheng and Al-Hawamdeh (2002) examined the impact of internet-based technologies on the buyer side procurement function, help in enhancement of competitiveness along with barriers in adoption of e-procurement. Error! Reference source not found.Error! Reference source not found. shows an e-procurement process in the MRO supply chain.

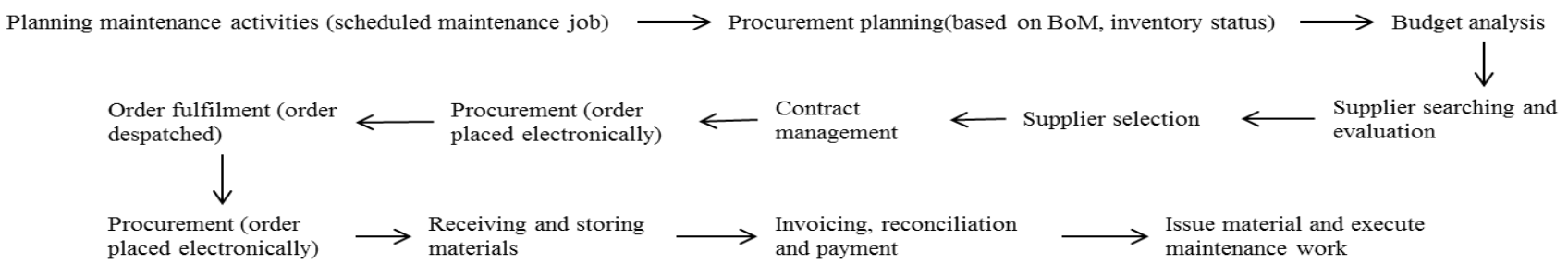

Figure 2 E-procurement Process Flow Chart 


\subsection{Benefits of E-procurement in the Supply Chain}

As per Aberdeen Group (2001) the non-production materials required for maintenance, repair and operation accounts for $30 \%$ to $60 \%$ of the company's total expenditure. So, successful implementation of eprocurement results in numerous benefits for the organisation. Moon (2005) mentioned that potential benefits of e-procurement are 1) lower transaction costs, 2) a faster ordering process, 3) wider vendor choice, 4) a standardized and more efficient procurement process, 5) greater control over procurement spending and better employee compliance, 6) more accessible internet alternatives for buyers, and 7) less paper work and fewer repetitious administrative procedures. Reduction in cost is directly induced by better negotiation with supplier, lower lead time and control over maverick buying process. The organisation comes to a better position to negotiate when they make planned purchases based on accurate forecast and planning from preferred suppliers. The suppliers are willing to cut the price when they get purchase assurance from the company (Parida et al., 2006) and also attempt to deliver goods on time to maintain the flow of contracts from the buying organisations. In this way the relationship of trust and assurance is being built between suppliers and company and in turn helps the company reduce inventory carrying cost.

\subsection{Potential Risks Involved in E-procurement}

In order to achieve the abovementioned benefit the organisation needs to overcome any barriers that slow down the implementation of e-procurement. Paper-based purchasing systems still dominate the maintenance world and $86 \%$ of MRO order transactions are not online and $84 \%$ of MRO payments are processed by paper (Foroughi, 2007, Aberdeen group, 2006). According to Davila et al., (2003) risks are broadly classified into four categories.

1) Internal business risks means companies are not sure whether they have appropriate resources for successful implementation of e-procurement systems as these systems not only require successful operation of purchasing process but also need to be integrated with the existing information infrastructure such as accounting, human resource, inventory management etc.

2) External business risks indicate e-procurement solutions need to interact with internal information systems along with external constituencies like customers and suppliers. External constituencies need to develop internal systems to communicate electronically.

3) Technology risks are related with the lack of widely accepted standards for coding, technical, process specification and clear understanding of eprocurement technology that can block the integration of different e-procurement software across the supply chain.

4) E-procurement process risks are associated with security and control of e-procurement processes. Organisations must ensure that unauthorized actions not disrupt supply chain activities.
As per above discussion, it is evident that MRO procurement is as important as procurement of direct material and has significant impact in enhancing value chain performance of an organisation. Previously MRO procurement predominantly followed traditional procurement process but due to considerable problems encountered in that process, there has been a substantial trend moving away from traditional procurement to eprocurement. Literatures suggest many benefits for eprocurement in a MRO environment and the purpose of this study is to assess whether those benefits are being realised or not. This study examines a case history of a helicopter servicing company in India where stages before and after implementation of e-procurement have been analysed to identify significant differences between the traditional and e-procurement process and the areas where e-procurement provides efficiencies and benefits in improving supply chain performance.

\section{METHODOLOGY USED IN THE CASE STUDY}

To achieve the desired objectives of the study and to find an answer to the research problem, this study has undertaken a qualitative single case study approach. Qualitative study offers a great deal of closeness to the respondents (Parida et al., 2006). The advantages of qualitative research are use of open-ended questions that give participants the opportunity to respond in their words rather than forcing them to select from fixed responses and also to allow the researcher the flexibility to probe. For this paper qualitative case study approach is more effective as the purpose of this study is to describe and find significant differences between traditional and e-procurement processes and to explore how e-procurement enhances performance of MRO supply chain over traditional process. The case study method is useful for testing theoretical models using a real world situation. In other words this is particularly suitable for understanding phenomena which requires knowledge of organisational context (Yin, 2003). The case study presented in this paper has involved a helicopter servicing company in India (Company A) as the case site and examine the process followed before and after implementation of an eprocurement system. The reason for considering these two situations gives true insight into why this is worthwhile as the procurement process of MRO supply chain has to be shifted from paper oriented traditional cumbersome process to electronic medium.

Data was collected from multiple sources, including formal interviews, internal documents, and website of the company. However, among these sources the most preferable are the interviews because rich insights and contextual information can be obtained from the key informants. The questionnaire has been developed to conduct semi-structured personal interviews to gather information about comparative differences between the processes and the benefits of e-procurement that enhances the SCM performance mentioned in literature review playing a role in reality. A total of fifteen in-depth interviews were conducted from several key informants, 
some of whom are purchase decision makers such as General Manager of Procurement and SCM, Procurement Manager, Assistant Manager Purchase, Buyers, and Store manager. Other respondents are from finance departments that reflect information on financial impact, and aviation maintenance engineers who send the requisition for procuring spare parts, equipment for servicing of helicopters and external parties involved in supply chain like freight forwarders, custom handling agents etc.

\section{CASE STUDY ON A HELICOPTER MRO ORGANISATION IN INDIA}

\subsection{Case Description}

Company A is a private helicopter maintenance, repair and overhaul (MRO) company in India. This company has the distribution agreement with the international helicopter manufacturing (OEM) company (B) based in France and Germany to act as a sole authorized distributor for their helicopters and spare parts in India and also a helicopter maintenance base for Indian customers. The company was established in the year 2006 but within a short period of time they were able to enlarge their customer base significantly, being a one stop solution for the customers. Their operations are not only limited to selling helicopter spare parts and provide maintenance services, they also maintain their own fleet of helicopters which they provide on rental basis for election flying and other purposes, providing pilots for customers helicopters and renting their helipad to be used by customers as and when needed. But for the sake of the study the analysis will be confined to the MRO division of the company. The company used to get service contracts from their customers for repair or maintenance of the helicopters and for that they need to procure spare parts, equipment, consumables and tools from company B and suppliers from all over the world for engines and other spare parts that are common to all helicopters.

\subsection{Methodology for the Assessment of $E$ - procurement and SCM Efficiency}

This case study will examine the entire procurement and SCM process. The assessment method (Panayiotou et al., 2004) applied here includes comparative assessment between process followed before and after implementation of e-procurement and compatibility of an e-procurement system to optimize SCM performance. In the first phase of the study, a traditional procurement process will be explained along with categories of procurement and type of customers. The second phase will highlight problems existing in traditional process which initiate implementation of e-procurement systems. The third phase will focus on the barriers that affect the implementation of an e-procurement framework and the process map after implementation of eprocurement. Finally, the last phase will discuss the results that company A experienced after shifting their procurement process from paper oriented traditional way to electronic medium. Figure 3 is showing the stages followed in the assessment method:

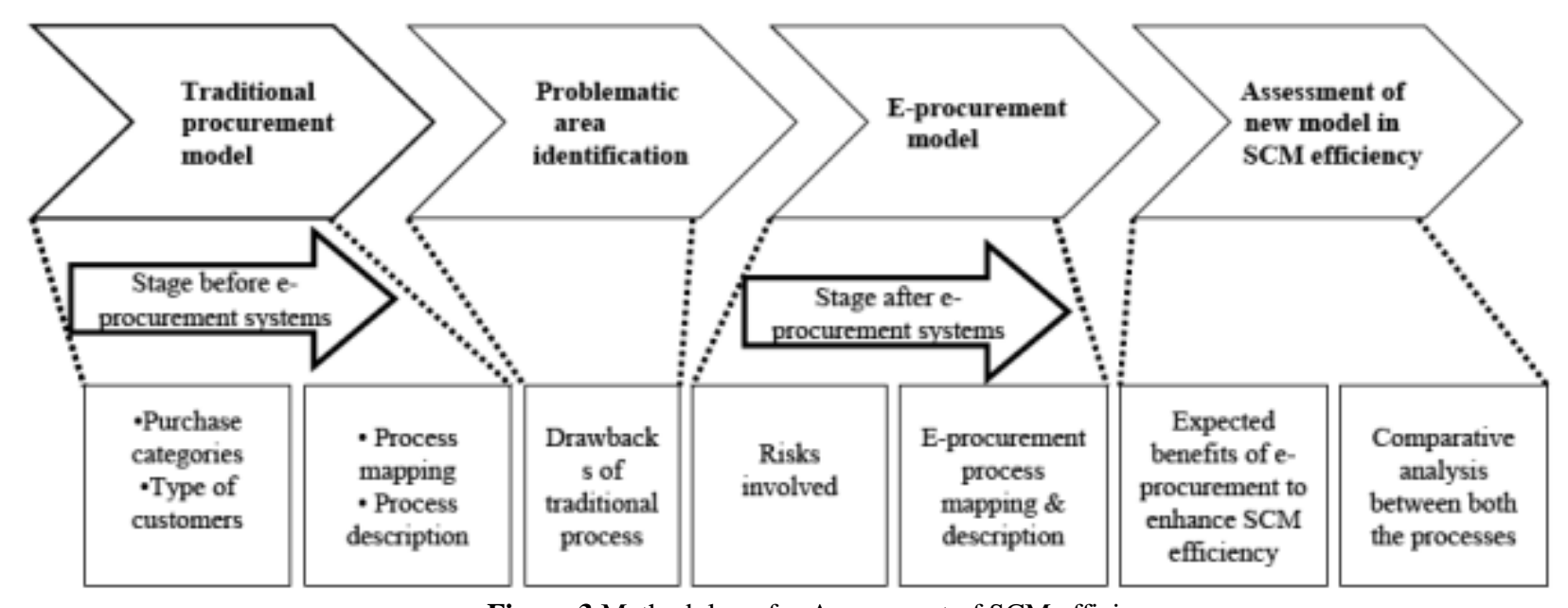

Figure 3 Methodology for Assessment of SCM efficiency

\subsubsection{Findings from Stage Concerning before $E$ - procurement Implementation}

Company A is basically involved in two types of maintenance strategy- 1) Preventative/Scheduled maintenance, and 2) Corrective/Failure maintenance. Preventative/scheduled maintenance happens before failure occurs. This is a periodic maintenance and repair activity required to be carried out from time-to-time and frequency of this maintenance dependent on schedules, ascertained after completion of certain flying hours by aircraft. Corrective maintenance occurs after technical and mechanical failure of system or components. This situation is known as Aircraft on ground (AOG) which is an utmost emergency situation in aviation industry that means the aircraft is grounded due to failure and the purpose is to make the aircraft fly again as soon as possible. Procurement required for this maintenance program is known as emergency (AOG) procurement and the stipulated time period for AOG procurement is normally 48 hours but that can change on the basis of availability of the products by suppliers. In AOG procurement suppliers are eager to supply the required items very quickly so the cost associated with AOG procurement is higher than routine procurement for preventative maintenance. Company $\mathrm{A}$ has to procure items for maintenance of helicopters for external customers and also for their own fleet. Their customer base varied from 
government companies to private organisations. Company A has $80 \%$ of their total procurement from overseas suppliers and $20 \%$ from local supply bases.
Figure 4 is showing the procurement dimension of company A which indicates the type of procurement and customers involved.

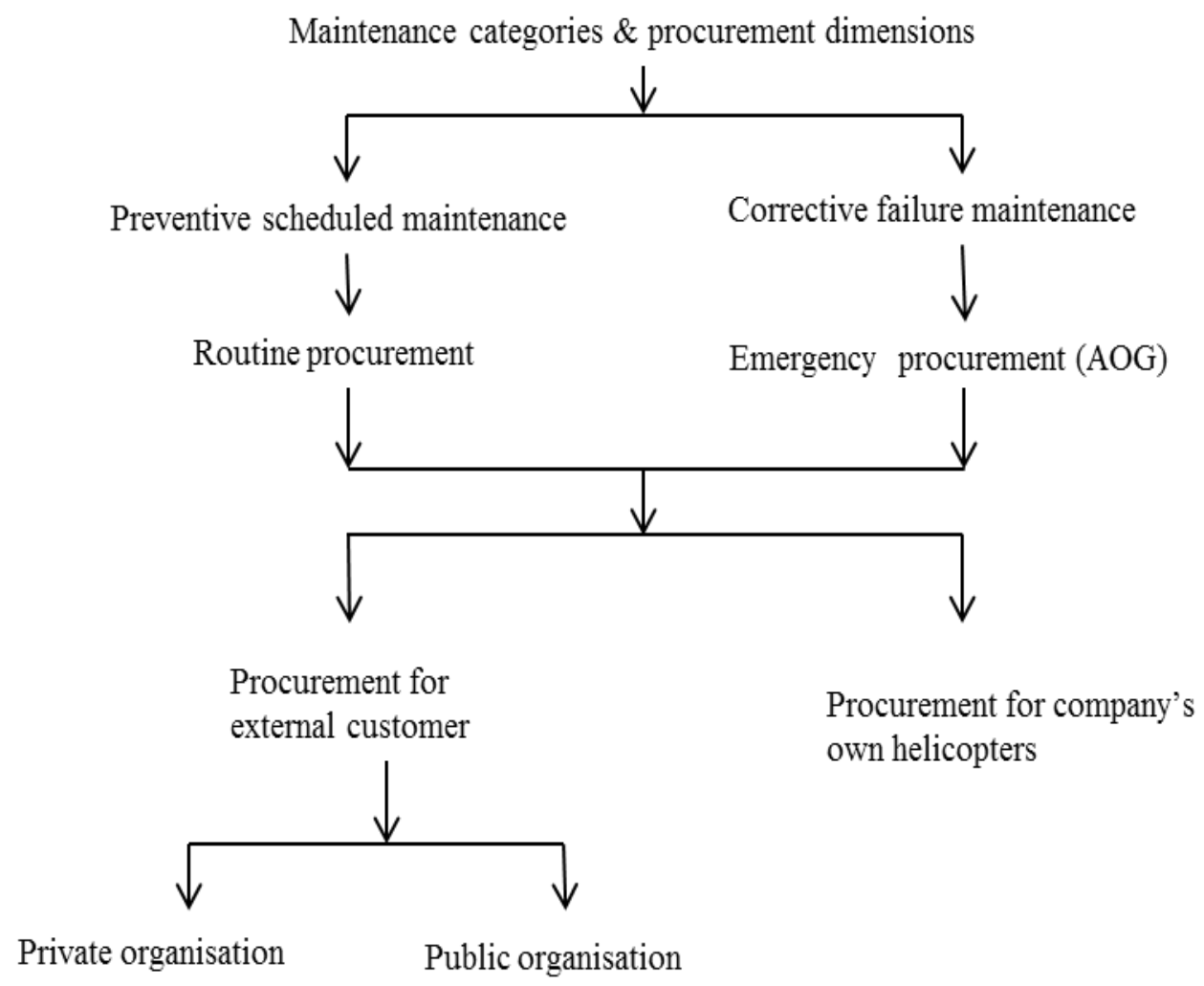

Figure 4 Procurement Dimensions of the Company

\section{Traditional procurement process}

The traditional process followed in the company A was time consuming and highly reliant on paper work. The aircraft maintenance engineer or engineering department sent requisitions to the procurement department along with technical specifications. Procurement department then checked the availability of the items with the store manager. If the items were available in inventory then the quality control (QC) department verified those items physically and approved those items for use in the helicopters. After obtaining approval from QC, stock was released from inventory as well as recorded in the issue register and the documents (Receipts) of the items were sent to the finance department for generating invoices for the customers. The customers preferred to pay the cost of the spare parts, equipment, consumables as and when they required separately apart from the maintenance contracts. If the required items were not available in the inventory, procurement activities took place.

The purchasing officer enquires about the items over the phone, fax or by sending requests for quotation/proposal (RFQ/ RFP) to different suppliers. After receiving quotations from different suppliers the price, lead time and terms and conditions of sale were evaluated and negotiated with suppliers. But most of the time due to urgency of the situation and delay in getting responses from vendors, company A had to make unplanned purchases at a higher price from the vendor who responded first. After technical and commercial evaluation, the purchasing officer selects the supplier and consequently prepares the contract or purchase order (PO) and supplier sends order acknowledgement after receipt of order.

When the shipments were ready to be delivered the supplier informs company A. Then the logistics department of company A informs nominated forwarder to take shipment into their custody from supplier premises as well as provide logistical instructions for shipments. After instruction the freight forwarder takes care of the shipment and sends a pre alert to company A, which is actually the shipment booking and arrival details along with all paperwork (airway bill, packing slip and commercial invoice). The logistics department then sends all the required documents to customs handling agent (CHA) for clearing the shipment in customs. In this process sometimes due to delay in getting information about shipment from supplier or freight forwarder, shipment would to stay in the custody of different parties longer than usual. After receiving shipment, the procurement department maintained all records of purchase and checks all the invoices from various parties (suppliers, FF, CHA) before sending invoices to the finance department for payment.

Figure 5 shows the traditional procurement process followed by the company. 


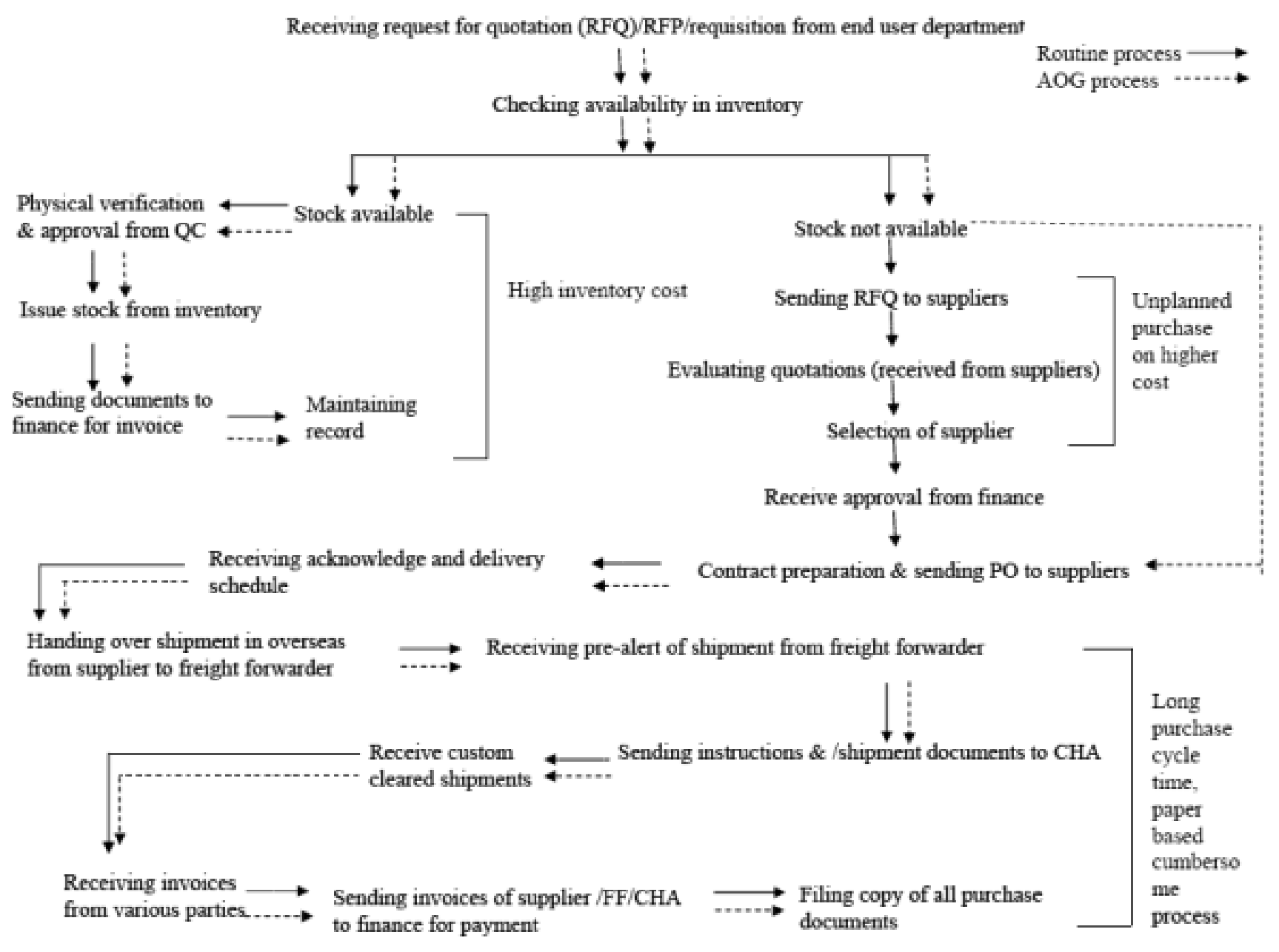

Figure 5 Traditional Procurement (Paper based) Process Followed in the Company A

\subsubsection{Problems Encountered in a Traditional Process}

The traditional process was a paper oriented time consuming cumbersome process. There were several problems in the traditional process which impacted the performance of the company and even in customer satisfaction. Previously company A had a high inventory cost which had significant impact on their financial performance. Due to the long purchase cycle and paper based procedure the company had the tendency of maintaining the high level of inventory to avoid the delay in servicing. In the AOG situation the delay was unacceptable and in the absence of the item in inventory, company $\mathrm{A}$ has to make unplanned purchases at higher cost.

Here are the list of problems identified in the traditional procurement process:

- Less technology involved in the procurement process

- $\quad$ Long lead time

- High inventory cost

- High administrative cost for procurement

- Unplanned purchases and high volume of stock in inventory

- Various departments taking time in decisionmaking as lack of visibility
- High rate of manpower required in SCM \& procurement department

- High rate of errors due to mistakes and manual process

- Maintaining multiple filing \& supporting purchase documents

- $\quad$ Large number of documents as paper based process

- Difficulty in searching information and time consuming

- Difficulty in managing large database of the customers

- Poor standardisation in data management

- Less choices for the company

- High transportation cost if aircraft in AOG

\subsubsection{Findings After E-procurement Implemen- tation}

The drawbacks of traditional procurement process, increasing cost, gradually increasing customer base and inefficiency in the process, led company A to implement an e-procurement system and mechanism bundled with enterprise resource planning (ERP) software package, electronic data interchange (EDI) between parties, electronic catalogue etc. However, several obstacles occurred during implementation of the e-procurement system. Company A 
was concerned about cost of implementation of the system in the existing workflow, acceptance of the system by employees and the need for educating the users before dealing with the new system. In the supply chain there were suppliers and service providers unable to afford expensive information and communication technologies (ICT) thereby, hampering the success of the electronic procurement. Company A had concerns about the security of the process which means confidentiality of the information, prevention of tampering documents and restricting unauthorized access. In spite of several concerns, the system implementation automated the entire workflow capabilities of the organisation. E-procurement system has streamlined the procurement process by establishing an e-network where information exchanged electronically with all the parties involved in the process as well as between internal stakeholders which increased visibility and transparency. After implementation of the e-procurement system, several activities were performed by the company simultaneously compared to the previously involved higher cycle time when waiting for information and paper documents to arrive by mail. The end user department then sends system generated requisitions to the purchasing department. Then purchasing department quickly checks the status of the inventory in the system and starts searching for suppliers in the electronic catalogue. The next step is the evaluation of quotations and negotiation with suppliers on cost and terms of purchase. After finalising the supplier, the procurement department informs the finance department about the order to be placed and simultaneously sends electronic PO to the vendor.

Once the order is received by the supplier, company A gets acknowledgement and delivery docket electronically from supplier when order is ready to be collected. Upon receipt of delivery docket, company A provides logistics instructions to freight forwarder strategically for better management of transportation cost. Once the pre alert is received, the custom handling agents (CHA) are also informed about the arrival of the shipments. In this inter-connected network between various parties, company A has greater tracking control on accessing information about the status of shipment without waiting to be informed by relevant parties. Finally the company receives invoices from suppliers, forwarders and $\mathrm{CHA}$ for payment. Figure 6 explains eprocurement process in the company.

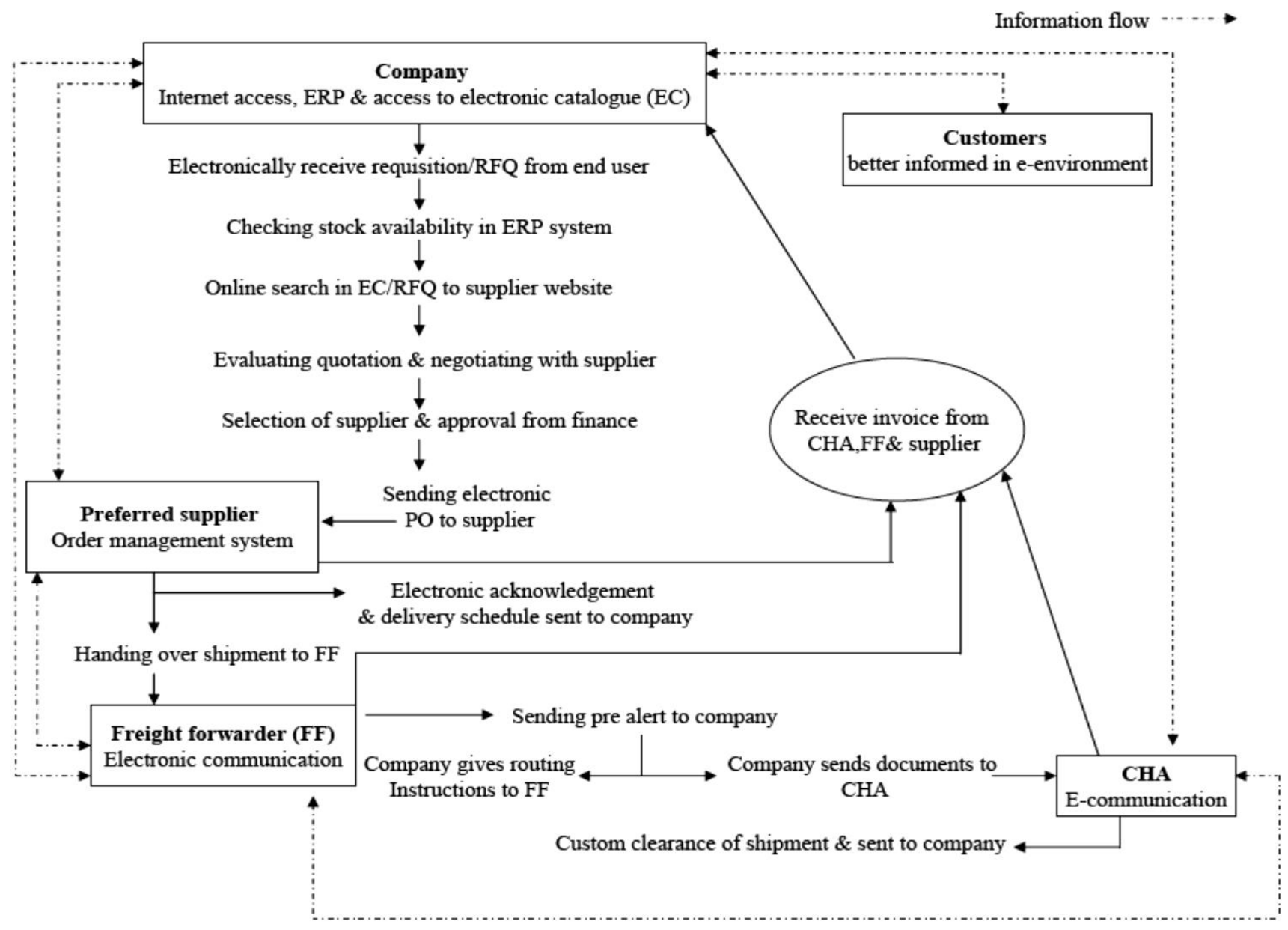

Figure 6 Electronic Procurement Process in Company A

\subsubsection{Assessment of E-procurement Systems in SCM Efficiency:}

E-procurement has considerably solved the problems encountered in traditional purchasing processes and improved SCM efficiency. The decision taken by the company A to implement e-procurement system has resulted in significant benefits for the company. Cost of procurement and operation which is considered as expensive business 
activity by (Rahim, 2008) has been reduced remarkably in the company. Now the company has better access to the supplier's system which helps them to evaluate and select preferred suppliers. Moreover better negotiation takes place between suppliers and company as both of them see mutual benefits. Purchase negotiation and better price help the company to reduce costs by ordering in bulk which in turn helps suppliers to reduce prices as they get purchase assurance from the company and want to maintain relationships with the company for long lasting business. Better relationship also ensures reduction in maverick buying process especially in AOG situations. Lack of communication and delay in receiving information in traditional processes was having a higher impact on costs as well as efficiency. By virtue of the electronic environment, associated parties involved in procurement processes internally and externally are having better information flow and control over processes. Reduction in paper-based work initiated higher accuracy rate, constructive activities rather than engaged in non-value added work, and transparency throughout the process.
This has streamlined the AOG and routine procurement processes in the company. As earlier mentioned, if the helicopter is in AOG situation in another part of the country most of the time due to the urgency of the situation, and with the communication gap and delay in getting shipment information before shipment gets landed in India, company A has to bear extra transportation costs to send the items from airport to the other part of the country. This scenario has changed as company now receives information electronically well in advance to plan its logistics activities with the concerned parties. The lead time for AOG shipment which was earlier seven to ten business days has dropped significantly to forty eight hours and for routine procurement, from three months to thirty days. Improved lead time, faster process, better communication and negotiation have reduced the level of inventory within the company and increased the performance of SCM. Table 1 is showing comparative difference between both the processes to enhance SCM efficiency.

Table 1 Comparative Differences between Processes on SCM Parameters

\begin{tabular}{|c|c|c|c|c|}
\hline \multirow[t]{2}{*}{$\begin{array}{c}\text { Supply chain } \\
\text { performance indicators }\end{array}$} & \multicolumn{2}{|c|}{$\begin{array}{c}\text { Traditional } \\
\text { procurement } \\
\text { process }\end{array}$} & \multicolumn{2}{|c|}{$\begin{array}{c}\text { Electronic } \\
\text { procurement } \\
\text { process }\end{array}$} \\
\hline & High & Low & High & Low \\
\hline Lead time & $\sqrt{ }$ & & & $\sqrt{ }$ \\
\hline $\begin{array}{l}\text { Inventory cost and cost of } \\
\text { procurement }\end{array}$ & $\sqrt{ }$ & & & $\sqrt{ }$ \\
\hline $\begin{array}{l}\text { Process efficiency, } \\
\text { transparency and control } \\
\text { over process }\end{array}$ & & $\sqrt{ }$ & $\sqrt{ }$ & \\
\hline $\begin{array}{l}\text { Customer satisfaction } \\
\text { and long term business } \\
\text { potential }\end{array}$ & & $\sqrt{ }$ & $\sqrt{ }$ & \\
\hline $\begin{array}{l}\text { Communication and } \\
\text { information management }\end{array}$ & & $\sqrt{ }$ & $\sqrt{ }$ & \\
\hline $\begin{array}{l}\text { Better quality } \\
\text { management }\end{array}$ & & $\sqrt{ }$ & $\sqrt{ }$ & \\
\hline
\end{tabular}

\section{CONCLUSION}

The purpose of the study is to highlight the importance of e-procurement for MRO to enhance supply chain performance of the aviation industry. For that the study has compared the significant differences between traditional process and e-procurement process of an aviation MRO company to identify the edge of an e-procurement system to increase SCM performance as discussed in the literature. It has been found in the literature that there is a tendency to follow traditional procurement process in MRO supply chain due to low volume and less importance of indirect materials (Puschmann and Alt, 2005). The traditional process followed in the organisation is time consuming, manual and paper based procedure. The process suffers from significant disadvantages like higher lead time, high volume of inventory to stop loss of shut down, increasing cost, less communication with the supply chain partners etc. These problems have initiated the need for implementation of an eprocurement system in the organisation. After 
implementation of an e-procurement system the process followed for procuring items remains the same but idle time has dropped drastically due to electronic communication and simultaneous execution of the processes. An e-procurement system has provided better communication and information exchange with the trading partners, transparency throughout the process, lower lead time, and increased the profitability through cost reduction and better customer satisfaction which leads to an efficient supply chain. This research has proved that transition to e-procurement has transformed the business model and value chain by enhancing operational and e-business performance. The outcome of the study will encourage MRO businesses to adopt and implement eprocurement to a great extent.

There is much scope for future research on assessing benefits of e-procurement for deciding transition into eprocurement. Although, present study is based on qualitative approach however, there is always good potential to ascertain the value gained through an e-procurement system applying quantitative measures. Irrespective of the nature of business sector, further research can also be extended to other business domain and more complex environment to optimize performance through e-procurement.

\section{REFERENCES}

Aberdeen group Inc. (2001). E-procurement: Finally ready for prime time white paper. Boston (MA) 14(2), pp.1-12.

Aberdeen Group Inc. (2006). The Maintenance, Repair and Operating Supplies Benchmark Report: Strategies for Improved MRO Spend Management.

Boer, L.D., Harink, J., and Heijboer, G. (2002). A conceptual model for assessing the impact of electronic procurement. European Journal of Purchasing \& Supply Management, 8, pp.25-33.

Chia, C. N. (1998). Increase your profit margin through electronic procurement. Journal of Internet Purchasing, 2(1), pp.100114.

Davila, A., Gupta, M., and Palmer, R. (2003). Moving Procurement Systems to the Internet: The Adoption and Use of E-procurement Technology Models. European Management Journal, 21(1), pp.11-23.

Farzin, S., Nezhad, H.T. (2010). E-procurement, the golden key to optimizing the supply chains system. World Academy of Science Engineering and Technology, 66, pp.518-524

Foroughi, A. (2007). MRO and e-procurement: Opportunities and Challenges. $5^{\text {th }}$ International Conference on Business Management, Athens Institute for Education and Research.

Gebauer, J., Beam, C., and Segev, A. (1998). Impact of the Internet on procurement. Acquisition Review Quarterly, 5(2), pp.167-184.

Gueritz, A. (2001), Understanding the benefits of e-procurement Article and White paper of Sixhills Consulting Ltd.

Gunasekaran, A., and Ngai, E.W.T. (2008). Adoption of eprocurement in Hong Kong: An empirical research. International Journal of Production Economics, 113, pp.159-175.

Gunasekaran, A., McGaughey,R,E., Ngai, E.W.T., and Rai, B.K. (2009). E-Procurement adoption in the Southcoast SMEs. International Journal of Production Economics, 122, pp. 161-175.

Jain, J., Dangayach, G.S., Agarwal, G., and Banerjee, S. (2010). Supply chain management: Literature review and some issues. Journal of Studies on Manufacturing, 1(1), pp.11-25
Kähkönen A., Lintukangas, N., \& Virolainen, K. (2013). The Effects of e-Business on Supply Management. Operations and Supply Chain Management 6(2), pp. 75-84.

Khandelwal, L. (2011), MRO Supply Chain Optimization in Manufacturing and Utility Industries, White Paper by Infosys.

Kheng, C.B., and Al-Hawamdeh, S. (2002). The adoption of electronic procurement in Singapore, Electronic Commerce Research. 2, pp. 61-73.

Kothari, T., Hu, C., Roehl, W.S. (2005). E-procurement: an emerging tool for the hotel supply chain management. International Journal of Hospitality Management. 24, pp.369-389.

Lambert, D., and Cooper, M. (2000). Issues in Supply Chain Management. Industrial Marketing Management. 29, pp. 6583.

Lancioni, R., Smith, M. F., Oliva, T. A. (2000). The Role of the Internet in Supply Chain Management. Industrial Marketing Management. 29, pp. 45-56.

Miah, S.J., Ahsan, K., \& Msimangira, K.A.B. (2013). An approach of purchasing decision support in healthcare supply chain management. Operations and Supply Chain Management, 6(2), pp. 43- 53.

Moon, M.J. (2005). E-procurement management in state governments: Diffusion of e-procurement practices and its determinants. Journal of Public Procurement, 5(1), pp.5472.

Olsen, B. E., Haugland, S. A., Karlsen, E., and Husøy, G. J. (2005) Governance of complex procurements in the oil and gas industry. Journal of Purchasing and Supply Management, 11(1), pp. 1-13.

Panayiotou, N.A., Gayialis, S.P., and Tatsiopoulos, I.P. (2004). An e-procurement system for governmental purchasing. International Journal Production Economics, 90, pp. 79102

Parida, V., Sophonthummapharn, K., and Parida, U. (2006). Understanding E-procurement: Qualitative Case Studies. Global Conference on Emergent Business Phenomena in the Digital Economy, 28 Nov - 2 Dec, Tampere, Finland.

Pires, G.D., Stanton, J. (2005). A research framework for the electronic procurement adoption process: Drawing from Australian evidence. Journal of Global Business and Technology 1(2), pp.12-20.

Power, D. (2008). Adoption of supply chain management enabling technologies: Comparing small, medium and larger organizations. Operations and Supply Chain Management, $1(1)$, pp.31-42.

Presutti Jr, W.D. (2003). Supply management and e-procurement: creating value added in the supply chain. Industrial Marketing Management, 32 (3), pp. 219-226.

Puschmann, T., and Alt, R. (2005). Successful use of eprocurement in supply chains. Supply Chain Management: An International Journal, 10(2), pp. 22-133.

Rahim, M. (2008). Identifying Factors Affecting Acceptance of Eprocurement Systems: An Initial Qualitative Study at an Australian City Council. Communications of the International Business Information Management Association, 3, pp. 7-17.

Teo, T.S.H., Lin, S., and Lai, K. (2009). Adopters and nonadopters of e-procurement in Singapore: An empirical study. Omega, 37, pp. 972-987.

Thomson, D., and Singh, M. (2001). An e-procurement model for B2B exchanges and the role of e-markets. In: Sixth annual collector conference on electronic commerce, Coffs Harbour, pp. 227-237.

Turban, E., King, D., Lee, J., and Viehland, D. (2008). Electronic Commerce: A Managerial Perspective. New Jersey: Person Education, Inc. 
Vaidya, K., Riquelme, H., Gao, J., and Soar, J. (2004). Implementing e-procurement initiatives: Impact of organisational learning across the public sector. Proceedings of "CINet2004"- 5 th International Conference on Continuous Innovation Network, Sydney, Australia, September, pp. 2225 .
Williams, S.P., and Hardy, C.A. (2007). E-Procurement: current issues and future challenge. $15^{\text {th }}$ European Conference on Information Systems, St Gallen, Switzerland.

Yin, K.K. (2003). Case Study Research: Design and Methods. $3^{\text {rd }}$ edition, Sage Publications Inc, Thousand Oakes, California, USA.

Munmun Basak is an experienced supply chain management professional. Currently, she is working in the Oil and Gas industry in Australia as a Sourcing Specialist - Contracts and Procurements. She has a post-graduate (MBA) degree from University of Petroleum and Energy Studies, India and B.Com (Hons) degree from Calcutta University, India. She is also a member of CIPS (Level III). Throughout her career she has worked in various industries including Aviation, EPCM and Oil and Gas. Her areas of interests are Contract Management, Strategic Procurement, and Supply Chain Risk Management. 